Abstracta Iranica

Revue bibliographique pour le domaine irano-aryen

Volume 32-33 | 2013

Comptes rendus des publications de 2009-2010

\title{
Ela Filippone. The fingers and their names in the Iranian languages
}

\section{Rüdiger Schmitt}

\section{Q OpenEdition}

1 Journals

Édition électronique

URL : http://journals.openedition.org/abstractairanica/40114

DOI : 10.4000/abstractairanica.40114

ISSN : 1961-960X

\section{Éditeur :}

CNRS (UMR 7528 Mondes iraniens et indiens), Éditions de l'IFRI

\section{Édition imprimée}

Date de publication : 1 décembre 2013

ISSN : 0240-8910

\section{Référence électronique}

Rüdiger Schmitt, «Ela Filippone. The fingers and their names in the Iranian languages », Abstracta Iranica [En ligne], Volume 32-33 | 2013, document 10, mis en ligne le 01 juillet 2016, consulté le 26 septembre 2020. URL : http://journals.openedition.org/abstractairanica/40114; DOI : https://doi.org/ 10.4000/abstractairanica.40114

Ce document a été généré automatiquement le 26 septembre 2020.

Tous droits réservés 


\title{
Ela Filippone. The fingers and their names in the Iranian languages
}

\author{
Rüdiger Schmitt
}

\section{RÉFÉRENCE}

Ela Filippone. The fingers and their names in the Iranian languages. (Onomasiological Studies on Body-Part Terms, I). Wien, Verlag der Österreichischen Akademie der Wissenschaften, 2010, 209 p. (Veröffentlichungen zur Iranistik, Nr. 55).

1 As part of a large-scale ethnolinguistic project on the terminology of body parts in Iranian languages, Filippone has collected, described and analyzed words for the fingers. Separate chapters deal with the fingers in general and with individual fingers, from the thumb to the pinkie. The extraordinarily rich material presented herein comes from not only dictionaries and glossaries, but also texts and interviews with native speakers. From an onomasiological viewpoint, it is interesting to observe that people can refer to fingers and even count with them (e.g., the quadrinary, quinary and decimal methods) in quite different ways. The fingers can be named according to their shape, position, use for special activities (e.g., killing lice with the thumb or licking a pot with the forefinger), etc. Names and naming procedures refer to symbolic and metaphorical uses. This book has detailed indexes and an makes for an interesting, sometimes even amusing, read. It is a pioneering work of relevance far beyond Iranian studies for research in cultural history. 


\section{AUTEURS}

\section{RÜDIGER SCHMITT}

Laboe 